\title{
Cross-Country Spillovers from Macroprudential Regulation: Reciprocity and Leakage
}

\author{
Margarita Rubio* \\ University of Nottingham
}

December 2019

\begin{abstract}
In a globally interconnected banking system, there can be spillovers from domestic macroprudential policies to foreign banks and vice versa, for example, through the presence of foreign branches in the domestic economy. The lack of reciprocity of some macroprudential instruments may result in an increase in bank flows to those banks with lower regulatory levels, a phenomenon known as "leakage." This may decrease the effectiveness of macroprudential policies in the pursuit of financial stability. To explore this topic, I consider a two-country DSGE model with housing and credit constraints. Borrowers can choose whether to borrow from domestic or foreign banks. Macroprudential policies are conducted at a national level and are represented by a countercyclical rule on the loan-to-value ratio. Results show that when there are some sort of reciprocity agreements on macroprudential policies across countries, financial stability and welfare gains are larger than in a situation of non reciprocity. An optimal policy analysis shows that, in order to enhance the effectiveness of macroprudential policies, reciprocity mechanisms are desirable although the foreign macroprudential rule does not need to be as aggressive as the domestic one.

Keywords: Macroprudential Policies, Spillovers, Banking Regulation, Foreign Branches, Leakage, Loan-to-value

JEL Classification: E44, F34, F41

\footnotetext{
${ }^{*}$ University of Nottingham, Sir Clive Granger Building, University Park, Nottingham, NG7 2RD, UK. E-mail: margarita.rubio@nottingham.ac.uk. This paper was presented at the 2017 ASSA meetings in Chicago, the INFINITI conference in Valencia, the WEAI conference in San Diego and the IFABS conference in Oxford. The author wants to thank conference participants for the comments received. The paper also received very valuable feedback at an ECB seminar. The author would like to thank seminar participants for their interest and discussion. Special thanks to Konstantin Kuck and Jongho Park, who discussed the paper at the INFINITI and the WEAI conferences, respectively. Also, thanks to the anonymous referee who evaluated my paper for the IFABS conference. All these comments have been carefully incorporated in the text. Special thanks to Harriet Lee for helping editing the text. All errors are mine.
} 
" The current framework already effectively addresses a number of risks emerging at national level. Yet, it is biased in selecting instruments to counter vulnerabilities at the national level while having a tendency to disregard cross-border implications, such as leakages, which may weaken the overall macroprudential stance.". Speech by Vítor Constâncio, Vice-President of the ECB, at the joint conference organized by the European Commission and the European Central Bank "European Financial Integration and Stability," 27 April 2015.

\section{Introduction}

In the aftermath of the financial crisis, there is consensus on the need for macroprudential policies to smooth the level of leverage in the financial system and therefore enhance its resilience. However, in a globally interconnected banking system, countries have less control over their own financial stability. Macroprudential measures may have cross-border spillover effects, which can go in different directions; they can be outward, when macroprudential policy affects conditions abroad. Or they can be inward, when foreign financial institutions are able to circumvent the national macroprudential policy. In this case, reciprocity agreements may be desirable.

In this paper, I focus on inward (or "waterbed") spillovers from macroprudential policy. National policies to contain risks from a rapid build-up of domestic credit can lead to an increase in the share of credit that is provided across borders, a phenomenon that has come to be known as "leakage." Thus, foreign banks can "undo" the intended effects of the domestic regulatory action. One example of such spillovers is where branches of foreign banks increase lending as a result of tighter financial regulation on domestic banks, if they are not subject to the same regulation as domestic banks. Then, if there is no reciprocity in policies across countries, that is, different regulatory regimes, credit activities may move from the regulated system to the non-regulated one. ${ }^{1}$

This cross-border arbitrage can occur through direct lending by cross-border banks to domestic borrowers, lending locally by foreign branches, as well as a rebooking of loans, whereby credit is originated by subsidiaries, but then booked on the balance sheet of the parent institution. The distinction between branches and subsidiaries is relevant as only subsidiaries are subject to the regulatory conditions of their host country. Branches, in the absence of reciprocity arrangements, are not bound by domestic macroprudential policy measures. Although subsidiaries are subject to the regulatory conditions in the

\footnotetext{
${ }^{1}$ The same argument could apply to shadow banking within the country.
} 
host country, a large share of subsidiaries in one country can indicate substantial potential for regulatory arbitrage when financial intermediation that previously took place via subsidiaries is shifted to branches, or if subsidiaries are converted into branches. In addition, these spillovers may occur if lending in the country is substituted with direct lending from the home country of the banking group. In either case, the financial intermediation would no longer fall within the realm of macroprudential policy in the host country.

There is evidence of inward geographical macroprudential spillovers in several countries. For instance, leakage effects seem to have complicated the response to national credit booms in a number of countries in Eastern Europe ahead of the crisis, e.g. in Bulgaria and Croatia (See Viñals and Nier, 2014). For the United Kingdom, Aiyar et al. (2012) estimate that just under a third of the reduction in credit growth that could have been achieved from increases in capital requirements on regulated banks was "undone" by an increase in lending by foreign branches that were not subject to the same requirements.

In light of this evidence, international spillovers through foreign banks' presence in a country matter for instrument effectiveness within a country's borders and are relevant for the broader issues of policy frameworks, reciprocity, and welfare. Leakage effects derived from foreign bank presence may call for cooperative action in the form of reciprocity in the conduct of macroprudential policy. The relevant policy question that arises then is how should reciprocity agreements be arranged so that macroprudential policies reach the highest levels of financial stability and welfare. The necessity of exploring these effects using a policy model is evident. This paper aims to fill this gap.

In this paper, I touch upon these issues, providing an analytical framework to disentangle the mechanisms behind the empirical evidence on the topic. I use a DSGE model with housing, and two types of agents; borrowers and lenders. Borrowers can borrow from domestic and foreign lenders and face collateral constraints when doing so. As in Iacoviello and Minetti (2006), I assume that foreign lenders have more difficulties in recovering domestic borrowers' assets and therefore, borrowers will have a preference for domestic lenders. Macroprudential regulators use the loan-to-value ratio (LTV) as a policy instrument. However, foreign lenders may not be subject to the same banking regulation as the host country, there may be lack of reciprocity. Within this setting, I study how domestic regulation affects the share of foreign borrowing, that is, if there are leakages coming from macroprudential policy. Then, I analyze how reciprocity agreements affect the dynamics of the model, financial stability and welfare. Finally, I perform an optimal policy analysis to assess the most effective macroprudential policy to maximize welfare, taking into account spillovers. 
This paper is related to several strands of the literature. First, it is closely related to studies that analyze macroprudential rules in a DSGE setting, such as Kannan et al. (2012), Rubio and CarrascoGallego (2014), or Angelini et al. (2014), among others. Nevertheless, this literature has not touched upon inward spillovers of macroprudential policies. To my knowledge, this is the first DSGE framework that explicitly introduces this issue. In fact, leakages have been mainly studied from an empirical point of view, as for instance in the above mentioned studies from Aiyar et al. (2012, 2014ab) for the UK. Therefore, this paper represents the theoretical counterpart to the literature that finds evidence on leakages from domestic macroprudential policy. It contributes to this literature by being able to analytically disentangle the mechanisms behind this phenomenon through a DSGE model suitable for policy evaluation and welfare analysis. In terms of modelling, this paper is also related to models that study how the presence of foreign lenders affects the economy. On this front, the closest paper to this research is Iacoviello and Minetti (2006). However, the latter paper abstracts from macroprudential policies. To my knowledge, this is the first time that this question is explored using a DSGE framework, which is extremely useful for policy evaluation.

Results show that, in the presence of foreign lending, macroprudential policy does leak. The share of domestic borrowing is not only inversely related to stricter domestic regulation, but also to loose regulation in foreign lending. Therefore, when domestic macroprudential policies do not reciprocate, inward spillovers appear. This has implications for financial stability and welfare. Macroprudential policies represent a welfare gain and an improvement in financial stability with respect to a situation in which there are not such policies. However, gains in terms of welfare and financial stability are larger under reciprocity agreements. I find that it is optimal for policies to reciprocate. However, given the preference of borrowers for domestic lenders, macroprudential policies should be applied less aggressively to foreign lenders than to the domestic ones.

The rest of the paper continues as follows. Section 2 presents some evidence on cross-country spillovers. Section 3 sets up the model. Section 4 displays results from simulations. Section 5 introduces macroprudential policies. Section 6 concludes.

\section{Evidence}

Evidence shows that there has been a great increase in the degree of financial services globalization in the past two decades, although the recent financial crisis has paused this trend. Many banks, from 


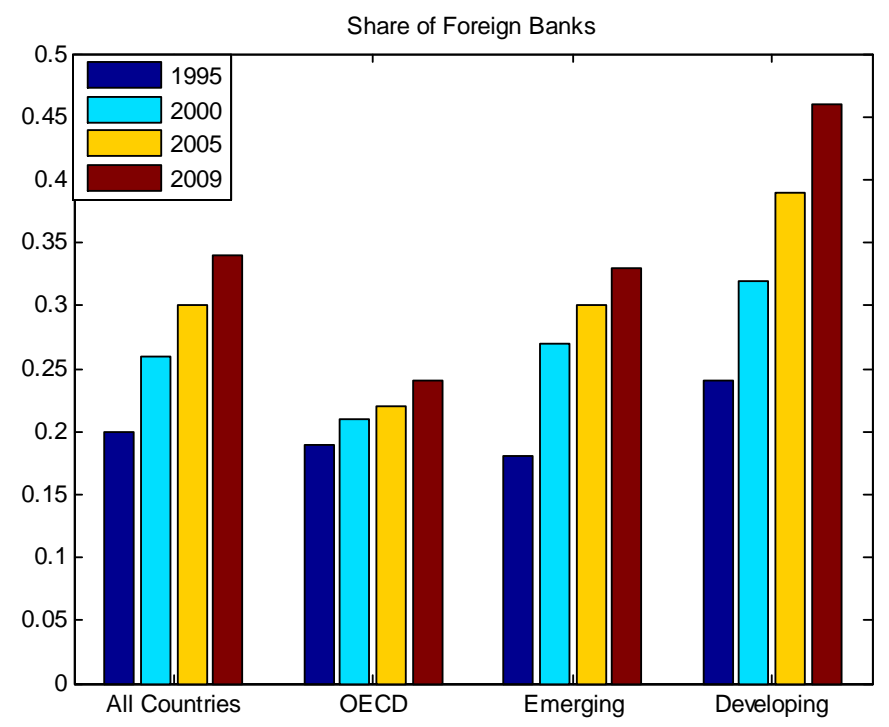

Figure 1: Share of foreign banks by regions. Source: Claessens and Van Horen, 2012

both advanced and developing countries have established their presence in other countries and provided financial services to their citizens. As a result, foreign banks have become important in domestic financial intermediation. For example, in terms of loans, deposits and profits, current market shares of foreign banks average 20 percent in OECD countries and close to 50 percent in emerging markets and developing countries. Figure 1 shows the increasing share of foreign banks for all countries and disaggregated by regions (OECD, emerging and developing economies). The share is calculated as the number of foreign banks divided by the number of domestic banks in the host country.

This increasing share of foreign bank presence opens the debate on reciprocity. In accordance with the Capital Requirements Regulation, reciprocation of a macroprudential measure refers to the application of the measure by other countries for bank activities in the country that initially adopted that measure. Lack of reciprocation may open up the possibility of regulatory arbitrage by cross-border banking groups that are able to shift their activities between group entities across borders and as a result, reduce the effectiveness of the macroprudential measure. In the EU, with few exceptions, reciprocation by other Member States is typically voluntary. ${ }^{2}$

Therefore, LTV regulation and reciprocity is an important concern of policy makers, which is supported by the data. There is evidence of cross-border spillovers in many European countries. This issue is particularly important for the UK financial system as foreign banks constitute a large share

\footnotetext{
${ }^{2}$ For instance, in December 2014, De Nederlandsche Bank (DNB) notified its decision to reciprocate the measure on residential mortgage lending adopted by the Banque Nationale de Belgique (NBB) in December 2013. DNB decided to apply the same measure to mortgages on residential real estate issued through branches of Dutch banks located in Belgium.
} 
of the market, providing around half of all lending to UK borrowers, and over $60 \%$ of lending in the interbank market. In the UK, there are more than 150 branches and approximately 100 subsidiaries of multinational banks operating in the country and, in addition, there a number of banking groups operating under both organizational structures. The UK is a paradigmatic example that has been vastly studied (see for instance Aiyar et al., 2014, Danisewicz et al., 2015). The UK has had an increasing share of foreign bank and foreign bank assets with respect to total assets in the past decade (See figures A1 and A2 in the appendix). And given the increasing importance of foreign banks in this economy, there is evidence of both spillovers from domestic macroprudential policies to foreign banks operating in the UK and also spillovers from foreign macroprudential policies to banks operating in the UK. Foreign bank branches in the UK are subject to home country regulatory policies only. Empirical work shows that when capital requirements are tightened for the UK banks, loan supply significantly diminishes. However, about a third of the effect is offset by foreign branches in the UK. Thus, any tightening in capital requirements would have to be coordinated with the home supervisor of the foreign branches, so that they tighten capital requirements for UK exposures as well (See Arregui et al., 2013). Aiyar et al. (2014ab) also find evidence of spillovers from domestic macroprudential policies to foreign banks operating in the UK, as well as leakage across UK financial sub-sectors. They also show that foreign bank branches increased their lending in the UK in response to tighter measures applied to local banks, a sign of cross-border competition and regulatory arbitrage. Their study concludes that leakages have weakened policy effectiveness in the UK.

This trend is similar in the US. If we look at figure A3 in the appendix, we see an increasing share of foreign loans in the US economy.

In Europe, cross-border flows are mostly from foreign parent banks into their subsidiaries, which take advantage of the growth opportunities and competed for market share with other foreign banks. Tightening of local regulatory policies often leads the parent banks to lend directly to the private sector. According to the 2015 edition of the ECB Financial Stability Review, in the EU countries, banking activity by foreign banks is predominantly conducted via subsidiaries. Foreign subsidiaries exhibit the greatest amount of activity in the smaller EU countries while foreign branches exhibit the greatest amount of activity in northern European countries. The ratio of foreign subsidiaries' assets to GDP is greater than 50\% in Ireland, Belgium, Luxembourg, Denmark, Finland, Estonia, Latvia, the Czech Republic, Slovakia, Croatia, Bulgaria and Cyprus. The same ratio for branches reveals that assets in foreign branches exceed 30\% of GDP in Ireland, the United Kingdom, Belgium, Estonia and Cyprus. 
Table 1 summarizes these facts:

Table 1: EU Countries

\begin{tabular}{|c|c|c|c|}
\hline & Share of foreign loans (2014) & Foreign subsidiaries assets/GDP (2013) & Foreign branches assets/GDP (2013) \\
\hline IE & $52 \%$ & $50 \%$ and above & $30 \%$ and above \\
\hline ES & $10 \%$ & $0-10 \%$ & $10-20 \%$ \\
\hline GB & $44 \%$ & $10-25 \%$ & $30 \%$ and above \\
\hline FR & $24 \%$ & $10-25 \%$ & $0-10 \%$ \\
\hline $\mathrm{BE}$ & $48 \%$ & $50 \%$ and above & $30 \%$ and above \\
\hline $\mathbf{L U}$ & $80 \%$ & $50 \%$ and above & $30 \%$ and above \\
\hline DK & $16 \%$ & $50 \%$ and above & NA \\
\hline $\mathrm{DE}$ & $25 \%$ & $10-25 \%$ & NA \\
\hline SI & $15 \%$ & $25-50 \%$ & $10-20 \%$ \\
\hline MT & $64 \%$ & $10-25 \%$ & $10-20 \%$ \\
\hline IT & $8 \%$ & $10-25 \%$ & $10-20 \%$ \\
\hline SE & $27 \%$ & $0-10 \%$ & $20-30 \%$ \\
\hline $\mathrm{CZ}$ & $16 \%$ & $50 \%$ and above & $10-20 \%$ \\
\hline AT & $29 \%$ & $25-50 \%$ & $10-20 \%$ \\
\hline HR & $10 \%$ & $50 \%$ and above & $0-10 \%$ \\
\hline SK & $13 \%$ & NA & NA \\
\hline HU & $7 \%$ & NA & NA \\
\hline BG & $17 \%$ & $50 \%$ and above & $0-10 \%$ \\
\hline GR & $12 \%$ & $0-10 \%$ & $0-10 \%$ \\
\hline FI & $33 \%$ & $50 \%$ and above & $20-30 \%$ \\
\hline EE & $22 \%$ & $50 \%$ and above & $30 \%$ and above \\
\hline RO & $5 \%$ & $25-50 \%$ & $0-10 \%$ \\
\hline CY & $26 \%$ & $50 \%$ and above & $30 \%$ and above \\
\hline LV & $39 \%$ & $50 \%$ and above & $10-20 \%$ \\
\hline
\end{tabular}

Source: ECB 2015. Note: Interbank cross-border loans as a percentage of borrowers'

total assets/Foreign subsidiaries' total assets as a percentage of GDP/Foreign branches' total assets as

a percentage of GDP 
This evidence raises concerns among EU policy discussions. In fact, according to the European Systemic Risk Board, ESRB (2016), in some EU countries (Bulgaria, Italy, Poland, Slovakia, Spain) current LTV limits apply to domestic banks only, while in others they also apply to foreign branches

(Cyprus, Lithuania, Romania, Sweden). The ESRB has set this issue as one of its priorities, due to the unintended effects that these policies may have in this context.

\section{$3 \quad$ Model Setup}

I consider an infinite-horizon two-country economy. The economy is populated by the same measure of infinitely lived agents, lenders and borrowers. Both types of households work, consume the final good and housing services; Borrowers can borrow and choose whether to borrow from domestic or foreign lenders. In borrowing, borrowers face credit constraints. Foreign lenders differ from domestic lenders in their ability to recover value from borrowers' assets and, therefore, to protect themselves against contractual non-enforceability. The two countries are symmetric and therefore, without loss of generality, and given that in this paper I just focus on the domestic economy, only the latter is described hereafter.

\subsection{Borrowers}

Borrowers maximize their lifetime utility from the consumption flow. I denote with $E_{t}$ the expectation operator conditional on time $t$ information and with $\gamma \in(0,1)$ the borrowers' discount factor. Borrowers solve the following problem:

$$
\max _{b_{t}^{H}, b_{t}^{F}, l_{t}, \alpha_{t}} E_{0} \sum_{t=0}^{\infty} \gamma^{t}\left(\ln c_{t}+j_{t} \ln h_{t}-\frac{\left(l_{t}\right)^{\eta}}{\eta}\right)
$$

subject to the flow of funds:

$$
c_{t}+q_{t}\left(h_{t}-h_{t-1}\right)+R_{t-1}^{H} b_{t-1}^{H}+R_{t-1}^{F} b_{t-1}^{F}=b_{t}^{H}+b_{t}^{F}+w_{t} l_{t}
$$

where $c_{t}$ and $h_{t}$ denote consumption and housing by borrowers, respectively. $b_{t}^{H}$ and $b_{t}^{F}$ represent domestic and foreign bond holdings, with their respective associated interest rates $R_{t}^{H}$ and $R_{t}^{F}$. $w_{t} l_{t}$ is the borrower's labor income. $j_{t}$ represents the weight of housing in the utility function. I assume that $\log \left(j_{t}\right)=\log (j)+u_{J t}$, where $u_{J t}$ follows an autoregressive process and $j$ is the steady-state value of the weight of housing. A shock to $j_{t}$ represents a shock to the marginal utility of housing. These shocks 
directly affect housing demand and therefore can be interpreted as a proxy for exogenous disturbances to house prices.

Assuming that $h_{t}$ is collateralizable, I denote $m_{H}$ the domestic loan-to-value for housing and $\alpha_{t}$ the share of collateral which is pledged to domestic lenders. $m_{F}$ is the loan-to-value for foreign lenders. Then, the borrower faces the following borrowing constraints:

$$
\begin{gathered}
R_{t}^{H} b_{t}^{H} \leq m_{H} \alpha_{t} q_{t+1} h_{t} \\
R_{t}^{F} b_{t}^{F} \leq q_{t+1}\left(1-\alpha_{t}\right) h_{t}\left(1-\left(1-m_{F}\right) \frac{q_{t+1}\left(1-\alpha_{t}\right) h_{t}}{q h}\right)
\end{gathered}
$$

As in Iacoviello and Minetti (2006), the collateral constraints with respect to domestic and foreign lenders are different to capture the idea that foreign lenders are likely to have limited experience in recovering and liquidating the assets of the borrowers. ${ }^{3}$ The main assumption of the model is the decreasing marginal ability of foreign lenders to extract value from borrowers' assets. This assumption is made to capture the idea that foreign lenders have limited local experience and knowledge, which can be put under more pressure than that of domestic lenders as the value of assets to be liquidated increases. ${ }^{4}$ There is empirical evidence that this might be the case. For instance, Rajan and Zingales (1998) argue that foreign lenders were exposed to such a problem in East Asian countries, where accounting standards and disclosure and bankruptcy laws were poorly drafted and enforced. Ramey and Shapiro (2001) also stress the importance of search costs in the redeployment of assets. The ability of a lender to identify efficient users is at least in part a by-product of the information gathered in previous credit relationships. Since foreign lenders have generally a shorter history in lending to local firms, they will likely have limited ability. Hermalin and Rose (1999) argue that foreign lenders face higher marginal monitoring and debt recovery costs than domestic lenders. Thus, it is reasonable to assume that gathering additional information is more costly for foreign lenders than for domestic ones: that is, the monitoring technology of foreign lenders exhibits decreasing returns to scale.

\footnotetext{
${ }^{3}$ The foreign lender expects to pay a convex cost $\left(1-m_{F}\right) E_{t}\left(\frac{1}{q h}\left(q_{t+1} h_{t}\right)^{2}\right)$ to dispose of the asset in case of debt repudiation, where $q h$ is just a steady-state normalization. Therefore, the value that the foreign lender can expect to recover from the sale of the asset is $E_{t}\left(q_{t+1} h_{t}-\frac{1-m_{F}}{q h}\left(q_{t+1} h_{t}\right)^{2}\right)$.

${ }^{4}$ The liquidation technologies imply that, for small values of assets, foreign lenders have a lower average liquidation cost than domestic ones. Otherwise, foreign lenders would be dominated by domestic ones and would never be chosen in equilibrium. However, for sufficiently high values of collateral, the advantage due to their organized offices is offset by the disadvantage due to their limited local experience.
} 
Borrowers choose labor and assets, how much to borrow from domestic and foreign lenders, and how to allocate shares $\alpha_{t}$ of assets between domestic and foreign financiers. The first-order conditions are as follows:

$$
\begin{gathered}
\frac{1}{c_{t}}=E_{t}\left(\frac{\gamma R_{t}^{H}}{c_{t+1}}\right)+\lambda_{t}^{H} R_{t}^{H} \\
\frac{1}{c_{t}}=E_{t}\left(\frac{\gamma R_{t}^{F}}{c_{t+1}}\right)+\lambda_{t}^{F} R_{t}^{F} \\
\frac{j_{t}}{h_{t}}=E_{t}\left(\frac{1}{c_{t}} q_{t}-\frac{\gamma q_{t+1}}{c_{t+1}}\right)+\lambda_{t}^{H} m_{H} \alpha_{t} q_{t+1}+\lambda_{t}^{F}\left(1-\alpha_{t}\right) q_{t+1}\left(1-\frac{2\left(1-m_{F}\right)\left(1-\alpha_{t}\right) q_{t+1} h_{t}}{q h}\right) \\
\lambda_{t}^{H} m_{H}=\lambda_{t}^{F} E_{t}\left(1-\frac{2\left(1-m_{F}\right)\left(1-\alpha_{t}\right) q_{t+1} h_{t}}{q h}\right) \\
w_{t}=\left(l_{t}\right)^{\eta}-1
\end{gathered}
$$

where $\lambda_{t}^{H}$ and $\lambda_{t}^{F}$ are the Lagrange multipliers of the domestic and foreign borrowing constraint, respectively. The first-order conditions are the consumption Euler equations (4 and 5), asset demand (6), choice of $\alpha_{t}(7)$, and labor supply (8).

From equations (4), (5), and (7), we can solve for $\alpha_{t}$ :

$$
\alpha_{t}=1-\frac{1-\left(\lambda_{t}^{H} / \lambda_{t}^{F}\right) m_{H}}{1-m_{F}} \frac{q h}{2 q_{t+1} h_{t}}
$$

If we find the value of $\alpha_{t}$ in the steady state, we obtain:

$$
\alpha=1-\frac{1-m_{H}}{2\left(1-m_{F}\right)}
$$

Therefore, in the steady state, the share of domestic collateral will be positively related to the average domestic loan-to-value ratio $\left(m_{H}\right)$ and inversely related to average foreign loan-to-value ratio $\left(m_{F}\right)$. In other words, credit will flow to the country with less strict regulation, that is, there are spillovers coming from LTV regulation. 


\subsection{Lenders}

Let us denote lenders variables with a prime. Lenders enter each period with assets and a bond coming to maturity. They derive utility from consumption, leisure and from housing. They rent labor and lend $b_{t}^{H}$ to domestic borrowers, $b_{t}^{F *}$ to foreign borrowers, and lend $b_{t}$ to foreign lenders, while receiving back the amount lent in the previous period times the agreed gross interest rates, respectively $R^{H}, R^{F *}$ and $R$.

Preferences are given by:

$$
\max _{b_{t}^{H}, b_{t}^{F *}, h_{t}^{\prime}, b_{t}, l_{t}} E_{0} \sum_{t=0}^{\infty} \beta^{t}\left(\ln c_{t}^{\prime}+j_{t} \ln h_{t}^{\prime}-\frac{\left(l_{t}^{\prime}\right)^{\eta}}{\eta}\right)
$$

where $\beta$ is the discount factor, which is assumed to be greater than $\gamma$, the discount factor for lenders. ${ }^{5}$

These households maximize (11) subject to the flow of funds:

$$
c_{t}^{\prime}+q_{t}\left(h_{t}^{\prime}-h_{t-1}^{\prime}\right)+b_{t}^{H}+b_{t}^{F *}+b_{t}=R_{t-1}^{H} b_{t-1}^{H}+R_{t-1}^{F *} b_{t-1}^{F *}+R_{t-1} b_{t-1}+w_{t}^{\prime} l_{t}^{\prime}
$$

Solution of this problem yields the following first-order conditions:

$$
\begin{gathered}
\frac{1}{c_{t}^{\prime}}=\beta E_{t}\left(\frac{R_{t}}{c_{t+1}^{\prime}}\right) \\
R_{t}^{H}=R_{t}^{F *} \\
R_{t}^{H}=R_{t} \\
w_{t}^{\prime}=c_{t}^{\prime}\left(l_{t}^{\prime}\right)^{\eta-1} \\
\frac{q_{t}}{c_{t}^{\prime}}=\frac{j_{t}}{h_{t}^{\prime}}+\beta E_{t}\left(\frac{q_{t+1}}{c_{t+1}^{\prime}}\right)
\end{gathered}
$$

where equation (13) represents the Euler equation for consumption. Equations (14) and (15) are the

\footnotetext{
${ }^{5}$ In a neighborhood of the steady state equilibrium, the multipliers associated with the entrepreneurs collateral constraints will be positive, so long as the entrepreneurial discount factor $\gamma$ is lower than the households' discount factor $\beta$, which in turn prices bonds.
} 
no-arbitrage opportunities conditions that will yield a single world interest rate in equilibrium. Equations (16) and (17) are the labor supply schedule and the asset demand schedule, respectively.

\subsection{Firms}

Firms produce the final consumption good. The problem for the final good firms is standard and static. They maximize profits subject to the production function by using labor from both types of households: ${ }^{6}$

$$
\begin{gathered}
\max \Pi_{t}=y_{t}-w_{t} l_{t}-w_{t}^{\prime} l_{t}^{\prime}, \\
y_{t}=A_{t} l_{t}^{\nu} l_{t}^{1-\nu},
\end{gathered}
$$

where $A_{t}$ represents a technology parameter. The problem delivers the standard first-order conditions, which represent the labor-demand equations:

$$
\begin{gathered}
w_{t}=\frac{\nu y_{t}}{l_{t}}, \\
w_{t}^{\prime}=\frac{(1-\nu) y_{t}}{l_{t}^{\prime}} .
\end{gathered}
$$

\subsection{Equilibrium}

The total supply of housing is fixed and it is normalized to unity:

$$
h_{t}+h_{t}^{\prime}=1
$$

The goods market clearing condition is as follows:

$$
y_{t}=c_{t}+c_{t}^{\prime}
$$

Labor supply (equations 8 and 16) and labor demand (equations 19 and 20) are equal to each other, so that labor markets also clear.

\footnotetext{
${ }^{6}$ Following the literature that starts with Kiyotaki and Moore (1997) and builds up with Iacoviello (2005) and Iacoviello (2015), I assume that output is produced with labor supplied from both agents. In this way I make this model comparable with the rest of the literature.
} 


\subsection{Welfare Measure}

As discussed in Benigno and Woodford (2008), the two approaches that have recently been used for welfare analysis in DSGE models include either characterizing the optimal Ramsey policy, or solving the model using a second-order approximation to the structural equations for a given policy and then evaluating welfare using this solution. As in Mendicino and Pescatori (2007), and Rubio (2011), we take this latter approach to be able to evaluate the welfare of the two types of agents separately. ${ }^{7}$ The individual welfare for domestic borrowers and lenders is defined, respectively, as follows:

$$
\begin{gathered}
V_{t} \equiv E_{t} \sum_{k=0}^{\infty} \gamma^{k}\left(\ln c_{t+k}+j \ln h_{t+k}-\frac{\left(l_{t+k}\right)^{\eta}}{\eta}\right) \\
V_{t}^{\prime} \equiv E_{t} \sum_{k=0}^{\infty} \beta^{k}\left(\ln c_{t+k}^{\prime}+j \ln h_{t+k}^{\prime}-\frac{\left(l_{t+k}^{\prime}\right)^{\eta}}{\eta}\right),
\end{gathered}
$$

Following Mendicino and Pescatori (2007), we define social welfare as a weighted sum of the individual welfare for the different types of households:

$$
W_{t}=(1-\gamma) V_{t}+(1-\beta) V_{t}^{\prime}
$$

Borrowers' and lenders' welfare are weighted by $(1-\gamma)$ and $(1-\beta)$, respectively, so that the two groups receive the same level of utility from a constant consumption stream.

To make results more intuitive, I present welfare changes in terms of consumption equivalents. The consumption equivalent measure defines the fraction of consumption that needs to be given up to equate the welfare under the new policy to the welfare under the baseline case (the policy is not active). A positive value means a welfare gain, hence indicates that the new policy is more desirable from a welfare point of view. The derivation of the welfare benefits in terms of consumption equivalent units is as follows:

$$
C E=\exp \left[(1-\gamma)\left(V^{M P}-V^{*}\right)\right]-1
$$

\footnotetext{
${ }^{7}$ I used the software Dynare to obtain a solution for the equilibrium implied by a given policy by solving a second-order approximation to the constraints, then evaluating welfare under the policy using this approximate solution, as in SchmittGrohe and Uribe (2004). See Monacelli (2006) for an example of the Ramsey approach in a model with heterogeneous consumers.
} 


$$
C E^{\prime}=\exp \left[(1-\beta)\left(V^{M P}-V^{*}\right)\right]-1
$$

where the superscripts in the welfare values denote the benchmark case when policy is not active and the case in which it is, respectively. ${ }^{8}$

\section{Simulations}

In order to gain some insight about the model, in this section I first show how the steady state proportion of domestic credit changes with the value of the LTV. Then, I present some impulse responses to see the dynamics of selected variables in the model, including the share of domestic lending, when the domestic economy is hit by a technology and a housing demand shock. The next subsection describes the parameter values used for calibration.

\subsection{Parameter Values}

The model time period is a quarter. As in standard models, $\beta=0.99$, implying an annual real interest rate of $4 \% ; \gamma=0.98$, so that borrowers are more impatient than lenders. ${ }^{9}$ The steady-state weight of housing in the utility function, $j$, is set to 0.1 in order for the ratio of housing wealth to GDP to be approximately 1.40 in the steady state, consistent with the US data. I set $\eta=2$, implying a value of the labor supply elasticity of $1 .^{10}$ The labor-income share for lenders is set to 0.64 , following the estimate in Iacoviello (2005). As in Iacoviello and Minetti (2006), the parameters describing the average liquidation ability (the LTVs) are set equal to $m_{H}=0.9$ and $m_{F}=0.8$ to reflect the fact that domestic lenders have a better liquidation technology than foreign ones. ${ }^{11}$ I assume that technology and housing demand

\footnotetext{
${ }^{8}$ I follow Ascari and Ropele (2009).

${ }^{9} \mathrm{I}$ have experimented with different discount rates and the leverage ratio, although it changes with the value of gamma, it does not show very large difference. For instance, the leverage ratio when gamma is 0.98 is 0.8764 , while when gamma is 0.95 is 0.8491 . Lawrance (1991) estimated discount factors for poor consumers at between 0.95 and 0.98 at quarterly frequency. I take the most conservative value.

${ }^{10}$ Microeconomic estimates usually suggest values in the range of 0 and 0.5 (for males). Domeij and Flodén (2006) show that in the presence of borrowing constraints these estimates could have a downward bias of $50 \%$.

${ }^{11}$ Given the liquidation technology, the steady state level of alpha, the share of domestic collateral, is equal to $75 \%$, whereas borrowers' domestic debt and foreign debt are, respectively, $150 \%$ and $50 \%$ of annual output. Total liabilities (credit market instruments, trade payables, taxes payable and miscellaneous liabilities) of Nonfinancial Businesses in the US count about $126 \%$ of GDP. The total liabilities of Households and Nonprofit Organizations were $84 \%$ of GDP. Thus, the total ratio private debt over GDP rises to $210 \%$. The total liabilities of Households and Nonprofit Organizations, as per Tables L.100 and L.101 in the US Federal Reserve Flow of Funds are about $84 \%$ of GDP. The total amount of US-owned assets abroad represents about $62 \%$ of GDP, whereas the total amount of foreign-owned assets in the US, as per BEA, accounts for $87 \%$ of GDP. Although this model does not differentiate between the various liabilities, these values of $150 \%$ for domestic and $50 \%$ for foreign debt fairly match these data.
} 


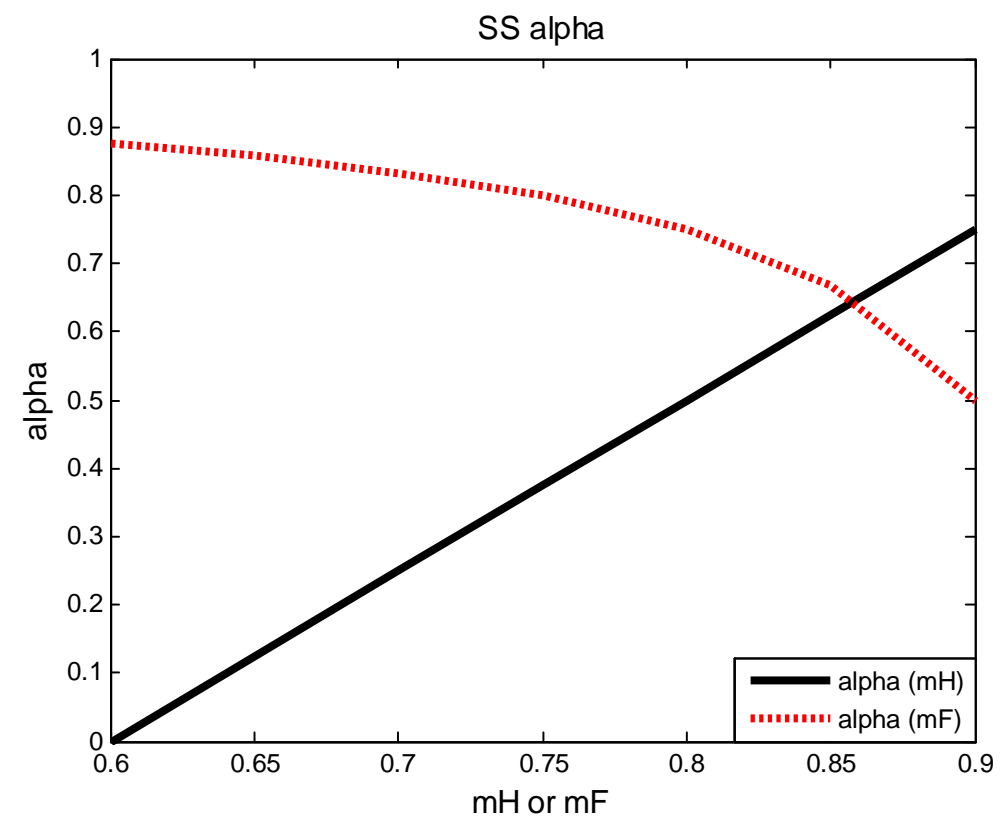

Figure 2: Steady state value of alpha for different domestic and foreign LTVs

follow an autoregressive process with 0.92 and 0.96 persistence, respectively, and a normally distributed shock with 0.01 and 0.04 standard deviation. ${ }^{12}$ Table 2 presents a summary of the parameter values used:

Table 2: Parameter Values

\begin{tabular}{|c|c|c|}
\hline \hline$\beta$ & .99 & Discount Factor for lenders \\
\hline$\gamma$ & .98 & Discount Factor for Borrowers \\
\hline$j$ & .1 & Weight of Housing in Utility Function \\
\hline$\eta$ & 2 & Parameter associated with labor elasticity \\
\hline$\nu$ & .64 & Labor-income share for lenders \\
\hline$m_{H}$ & 0.9 & Domestic LTV \\
\hline$m_{F}$ & 0.8 & Foreign LTV \\
\hline$\rho$ & .9 & Shock persistence \\
\hline
\end{tabular}

Note: Table 2 reports parameter values. 


\subsection{Steady-State alpha}

Figure 2 displays how the share of domestic borrowing changes with regulation on the LTV. ${ }^{13}$ The vertical axis reflects the value of $\alpha$ in the steady state, that is, the share devoted by borrowers to domestic borrowing. The horizontal axis displays the home and foreign LTV $\left(m_{H}\right.$ and $m_{F}$, respectively). Moving along the horizontal axis to the right would mean looser LTV regulation. The black line represents the change in the proportion of domestic borrowing when the domestic LTV changes, for given foreign LTV. This graph already gives us an idea on how domestic regulation affects this share, particularly if it is not accompanied by a change in regulation for foreign lenders in the same direction. These effects on the share would represent leakages from regulation. We see that when the domestic regulation becomes looser, that is, $m_{H}$ increases for a given $m_{F}$, credit from domestic lenders goes up in a linear way. There is a threshold at $m_{H}=0.6$, at which the regulation in the host country is so strict that all credit would flow abroad. Up to this point, loosening up the regulation would linearly increase the value of $\alpha$. On the other hand, keeping fixed $m_{H}$, making foreign regulation looser, for instance, increasing the LTV in foreign branches, makes the proportion of domestic credit decrease, since now credit constraints are looser abroad (red dotted line). Nevertheless, notice that this decrease is non linear, reflecting the decreasing marginal ability of foreign lenders to extract value from borrowers' assets. In other words, this could be interpreted as domestic borrowers having an intrinsic preference for domestic lenders. The punchline that can be extracted from the graph is that financial regulation does leak, that is, there are cross-border spillovers coming from regulation and credit will flow to the country in which the regulation is less strict.

\subsection{Impulse Responses}

In this subsection, I present impulse responses to a productivity and a housing demand shock, in order to understand how the dynamics of the model work. Both shocks are expansionary and make output and borrowing increase. Consumers are wealthier due to the shock and they are able to borrow more. However, the question that arises is whether this increase in borrowing is evenly distributed between domestic and foreign bonds. The choice of these two shocks intends to give a complete picture of the situation, given that they represent exogenous disturbances coming from both the supply and the demand

\footnotetext{
${ }^{12}$ I follow the estimates in Iacoviello and Neri (2010).

${ }^{13}$ For the benchmark calibration, the model generates a steady-state alpha of $60 \%$, meaning that borrowers borrow around $40 \%$ from foreign sources (branches and subsidiaries). According to the World Bank, in Europe and Central Asia, this percentage was $49 \%$ in $2008,46 \%$ in $2011,39 \%$ in 2014 , and $38 \%$ in 2015 . Therefore, the model moment matches data pretty closely.
} 

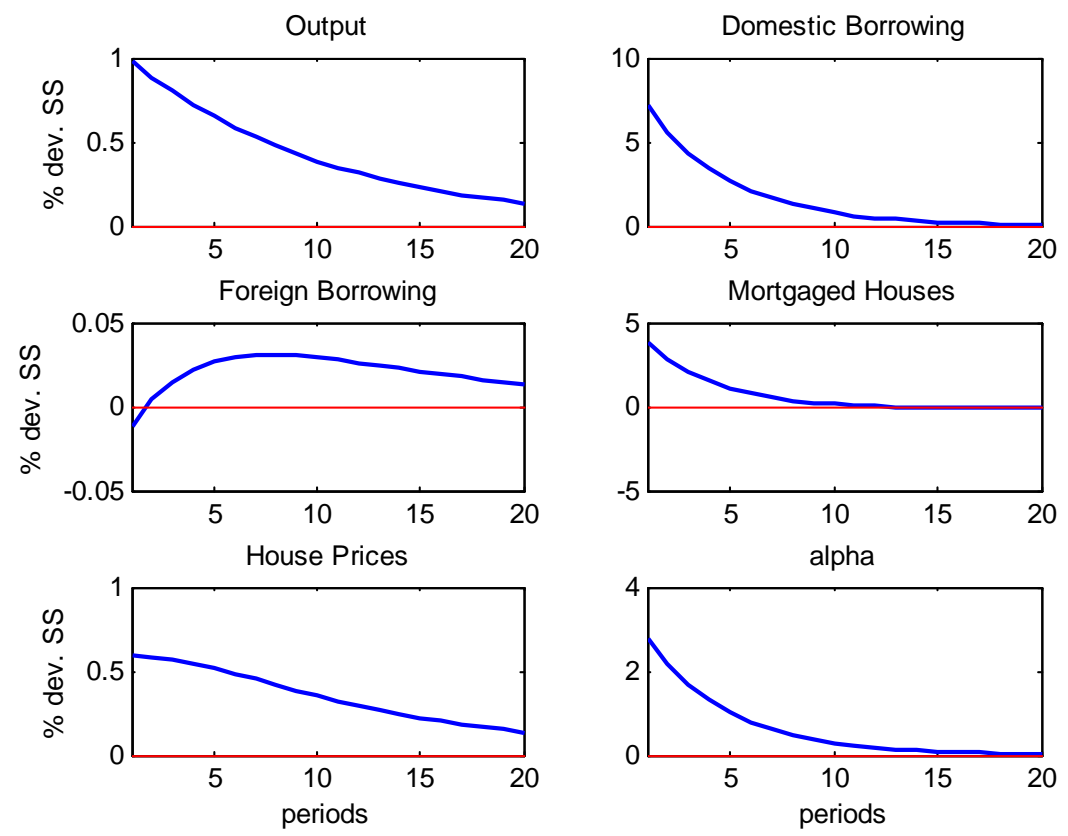

Figure 3: Impulse Responses to a Technology Shock

side of the economy, as well as from the real and housing sector.

Figure 3 presents impulse responses to a technology shock. We see that, given a positive productivity shock, output increases, as expected. This shock makes domestic borrowing increase because of its expansionary nature. Keeping fixed regulation and given the preference of borrowers for domestic lenders, $\alpha$, the share of domestic borrowing over total borrowing, increases, meaning that the expansion in credit is mainly domestic. Thus, there is a redistribution between domestic and foreign borrowing. Foreign borrowing also increases, but much less than the domestic one. The increase in credit makes the demand for mortgaged houses go up, also boosting up house prices. The increase in house prices acts as a feedback loop through collateral constraints and pushes up credit and output even further, representing the financial accelerator that is present in this model.

Figure 4 displays the impulse responses of the model to a housing demand shock. Housing demand shocks are translated directly to house prices, which is why in these type of models are usually interpreted as exogenous disturbances to house prices. A house price shock is transmitted to the macroeconomy through the collateral constraint. Higher house prices mean that the value of the collateral is higher for borrowers and thus can borrow more. Since future house prices enter in the collateral constraint, there is an initial slight drop in output, which is compensated by the increase in the collateral value in future periods. As in the previous case, we see that credit increases due to the shock but that borrowers 

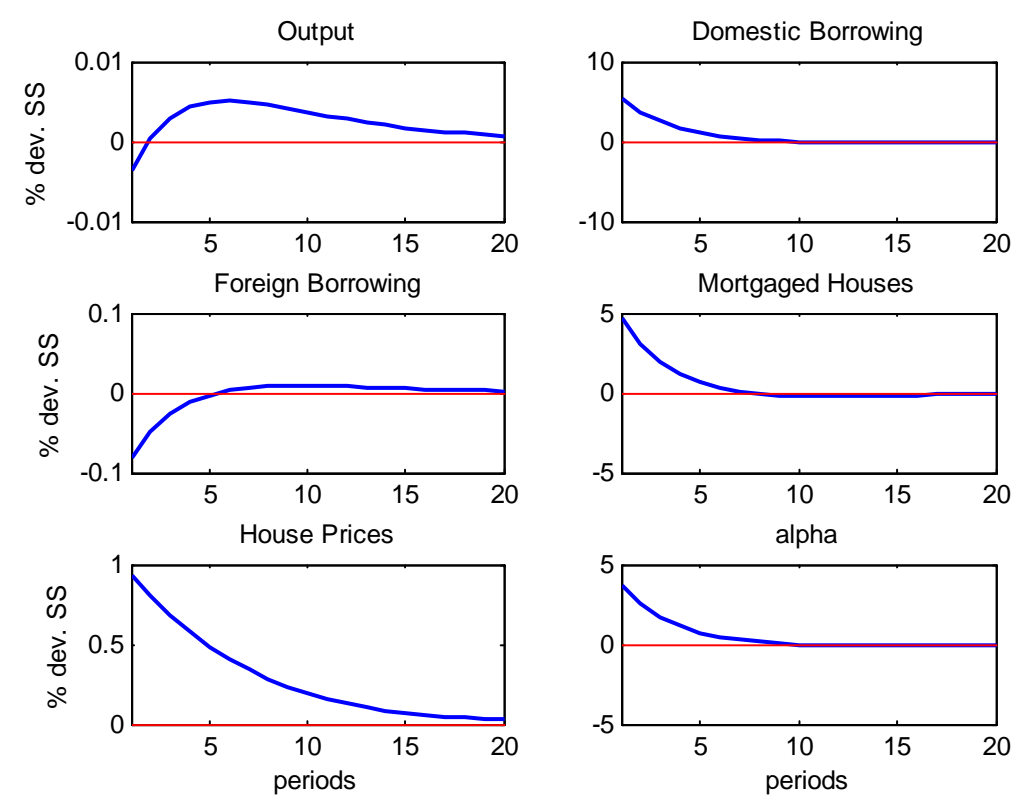

Figure 4: Impulse Responses to a House Price Shock

mainly increase domestic borrowing, slightly decreasing the borrowing from abroad, as a substitution effect. This latter effect may be at odds with the data, but the net effect is an increase in $\alpha$, the share of borrowing that comes from domestic lenders. This is a mechanism that can be explained by the optimal value of alpha (equation 9). The share of domestic borrowing rises with house prices. That is, increases in house prices involve a switch from foreign to domestic lenders. Thus, following a house price shock, transaction costs become relatively higher at the margin for the foreign lender. Hence, the amount of foreign borrowing rises in percentage less than the amount of domestic borrowing $(\alpha$ rises $) .{ }^{14}$ The increase in borrowing then pushes up mortgaged housing and consumption goods, bringing up in turn output and making this shock expansionary for the macroeconomy.

From these impulse responses we can see that expansionary shocks in the model trigger an increase in output and borrowing, but that this borrowing mainly comes from domestic sources.

\section{Macroprudential Policy}

In this section, I introduce macroprudential policies into the model, to assess the implementation of these kind of policies in the presence of foreign banks in the domestic economy. First, I present a countercyclical

\footnotetext{
${ }^{14}$ Although the decrease in foreign borrowing following a house price shock may seem odd, Iacoviello and Minetti (2003), using US time-series data, show that real estate values positively affect the importance of domestic versus foreign business loans.
} 
macroprudential rule on the LTV as a plausible approximation for macroprudential policy. Then, I analyze the effects of the lack of reciprocity in macroprudential rules for the dynamics of the model, financial stability and welfare. Finally, I present the optimal macroprudential policy to maximize welfare.

\subsection{Macroprudential rule}

As an approximation for a realistic macroprudential policy, the literature has considered Taylor-type rules on the LTV. ${ }^{15}$ In standard models, the LTV ratio is a fixed parameter, which is not affected by economic conditions. However, we can think of regulations of LTVs as a way to moderate credit booms. When the LTV is high, the collateral constraint is less tight. And, since the constraint is binding, borrowers will borrow as much as they are allowed to. Lowering the LTV tightens the constraint and therefore restricts the loans that borrowers can obtain. As stated in the introduction, the ESRB has identified the LTV as one of the potential macroprudential policies that in some cases is applied just domestically, while foreign banks may escape its jurisdiction.

Recent research on macroprudential policies has proposed Taylor-type rules for the LTV so that it reacts inversely to credit variables such as credit, the credit-to-GDP ratio or house prices. These rules can be a simple illustration of how a macroprudential policy could work in practice. In this model, I propose a rule in which the LTV responds to domestic house prices, as an indicator of credit conditions: ${ }^{16}$

$$
\begin{aligned}
& m_{H t}=m_{H}\left(q_{t}\right)^{-\phi_{H}}, \\
& m_{F t}=m_{F}\left(q_{t}\right)^{-\phi_{F}},
\end{aligned}
$$

where $m_{H}, m_{F}$ are the steady-state values for the LTV for domestic and foreign lending, respectively. $\phi_{H} \geq 0, \phi_{F} \geq 0$ measure the response of the two LTVs to house prices. This kind of rule would be countercyclical, delivering a lower LTV ratio in housing booms, therefore restricting credit in the economy.

\footnotetext{
${ }^{15}$ See for instance Kannan et al. (2012) or Angelini et al. (2014).

${ }^{16}$ An alternative would be letting the LTV respond to credit, which gives similar results. However, given that in this model there is domestic and foreign lending, it is not clear to which credit variable to respond. To make the modelling of the rule cleaner, I choose house prices as the relevant variable to respond. In any case, through collateral constraints, house prices and credit are directly related.
} 


\subsubsection{Reciprocity vs. Lack of Reciprocity}

Within this macroprudential setting, we can consider two cases: the case in which there is no reciprocity in policies between the two countries versus the case in which there is.

We can think of the first case, that is, non reciprocity, as for example, foreign branches of banks not following the regulation of the host country. Then, if there is a boom in housing markets in the host country, which makes credit conditions stricter in the domestic country, foreign branches do not necessarily follow this regulation. In this case, the above mentioned leakage phenomenon may appear; funds could flee to the less regulated sector, in this case foreign lenders. In terms of the model, I approximate this case to $\phi_{H}>0, \phi_{F}=0$. This means that the domestic country is actively using macroprudential policies to respond to developments in domestic housing markets but foreign lenders are not responding.

However, the two countries could reach some sort of reciprocity agreement, in which case, foreign branches will also have to follow regulations in the host country and thus $\phi_{H}>0, \phi_{F}>0$. In the case of reciprocity, I assume that $\phi_{H}$ and $\phi_{F}$ do not necessarily have to equal each other, given that liquidation technology of domestic and foreign lenders is different. As we have seen, in the model, borrowers have a preference for domestic lenders. Thus, to avoid corner solutions, I consider reciprocity as a situation in which, even though foreign branches are applying the macroprudential policy of the host country, it does not need to be as strict as for domestic lenders.

\subsection{Effects of Macroprudential Policies on Welfare and Financial Stability}

The lack of empirical evidence on macroprudential rules, makes it very difficult to calibrate the parameters of the macroprudential rule. Therefore, I find the optimal combination of parameters, both for domestic and foreign lenders, that maximizes welfare. Results are presented in Table $2:{ }^{17}$

\begin{tabular}{cccc}
\hline \hline Table 3: & Optimal Macroprudential Policy \\
\hline \hline$\phi_{H}^{O P T}$ & $\phi_{F}^{O P T}$ & $\sigma_{b^{T}}$ & Welfare Gain \\
8.5 & 0.2 & 0.102 & 1.32 \\
\hline
\end{tabular}

Note: Table 2 reports the values of the parameters in the macroprudential rule that maximize welfare.

We can observe from Table 3 that it is optimal, with the presence of foreign lenders in the domestic country, to have reciprocity in macroprudential policies. However, given that foreign lenders have more

\footnotetext{
${ }^{17}$ Welfare gains are presented in consumption equivalent units, that is, which fraction of consumption would agents be willing to sacrifice in order to be in a welfare superior outcome.
} 
difficulties in extracting value from borrowers' collateral, the optimal macroprudential rule needs to be less aggressive for foreign lenders. In particular, the first column of the table presents the optimized parameter for the domestic macroprudential rule. We see that the domestic rule needs to be aggressive in responding to housing market developments in order to achieve financial stability and maximize welfare gains. The optimized coefficient in the foreign macroprudential rule is positive, meaning that it is beneficial for welfare to reach some sort of reciprocity agreement between both countries, so that leakages are not as strong as in the non reciprocity case. However, the optimized coefficient for foreign lenders is smaller than the domestic one. This means that the macroprudential rule for foreign lenders, though it needs to be activated, does not have to be as aggressive as the domestic one. A very aggressive foreign macroprudential rule could imply no funds at all going to foreign lenders.

\subsubsection{Dynamics}

Here, I present impulse responses to illustrate how the dynamics of the model change when there are macroprudential policies, using the optimal values presented above. However, for completeness, I also consider a case of non reciprocity, that is, I also check what would happen if the macroprudential policy channel were shut down for foreign branches. The interpretations of non reciprocity is the following: the domestic country has macroprudential policies activated in the form of a countercyclical rule and responds to domestic housing conditions. When there is an increase in domestic house prices, LTVs decrease, making the regulation stricter. However, the LTV applied to foreign branches in the host country stays constant and does not vary with housing cycles. This situation would be, by definition, suboptimal but serves to quantify the welfare gains of reciprocity within the model. I perform these experiments for both a technology and a housing demand shock.

Figure 5 shows impulse responses for a technology shock. The black solid line represents the benchmark case, already displayed in the previous section, in which there are no macroprudential policies in place. I compare the benchmark with the case in which macroprudential policies are introduced. The blue dotted line corresponds to the optimal values, in which there is reciprocity in macroprudential policies, that is, given developments in housing markets in the domestic country, both domestic and foreign lenders apply a stricter macroprudential policy on their respective LTVs following a boom. We see that the overall effects of macroprudential policies on the aggregate macroeconomy, regardless of reciprocity, are very similar. This is coming because the effects are compensating in the aggregate between borrowers and lenders, there is a redistribution among agents. However, there seems to be 

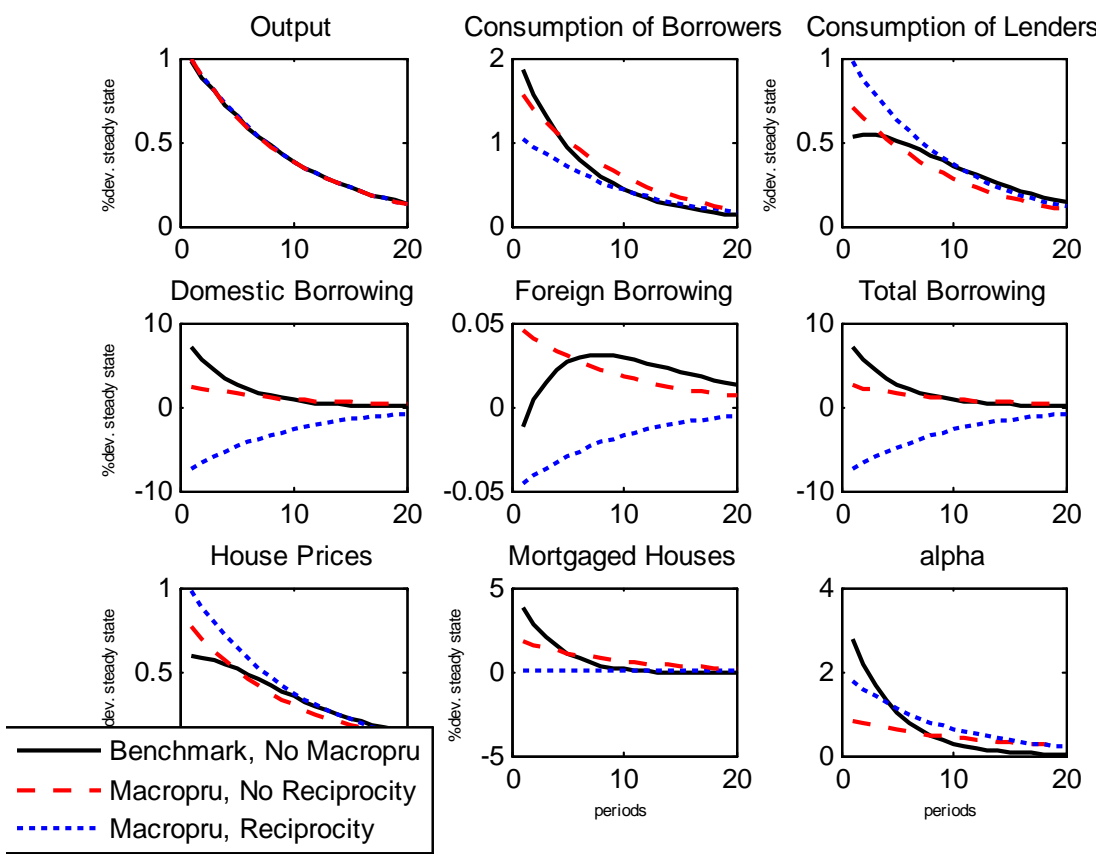

Figure 5: Impulse Responses to a Technology Shock

implications for financial markets. This is a common result in the macroprudential literature (See for instance Rubio and Carrasco-Gallego, 2014, Mendicino et al., 2015, or Chen and Columba, 2016). The trade-offs between borrowers and savers make that, in the aggregate, differences between scenarios are not that large. For consumption, changes in borrowers' are compensated by their savers' counterparts, given the structure between these two agents. However, macroprudential policies make a difference in affecting financial variables and cause distributional effects between agents. Total debt is increasing by less when there is reciprocity, meaning that the macroprudential policy is more effective in this case and more financial stability is achieved. There is also a difference in the distribution of debt between domestic and foreign among the three cases. We can see this if we look at the response of the share of domestic borrowing. Housing demand for borrowers shifts outward less with reciprocity because borrowing increases by less but savers also buy houses and they may demand more housing because now they do not need to save as much for the savers. These price dynamics follow from these general equilibrium effects. With macroprudential policies, if there is no reciprocity, since the regulation at home becomes stricter, $\alpha$ increases much less than for the benchmark, representing leakages from macroprudential policies. Therefore, when there is reciprocity in policies, there is not so much redistribution in debt, meaning that then, macroprudential policy does not leak as much as in the non reciprocity situation.

Figure 6 displays the dynamics of the model for a house price shock. The arguments for this type of 

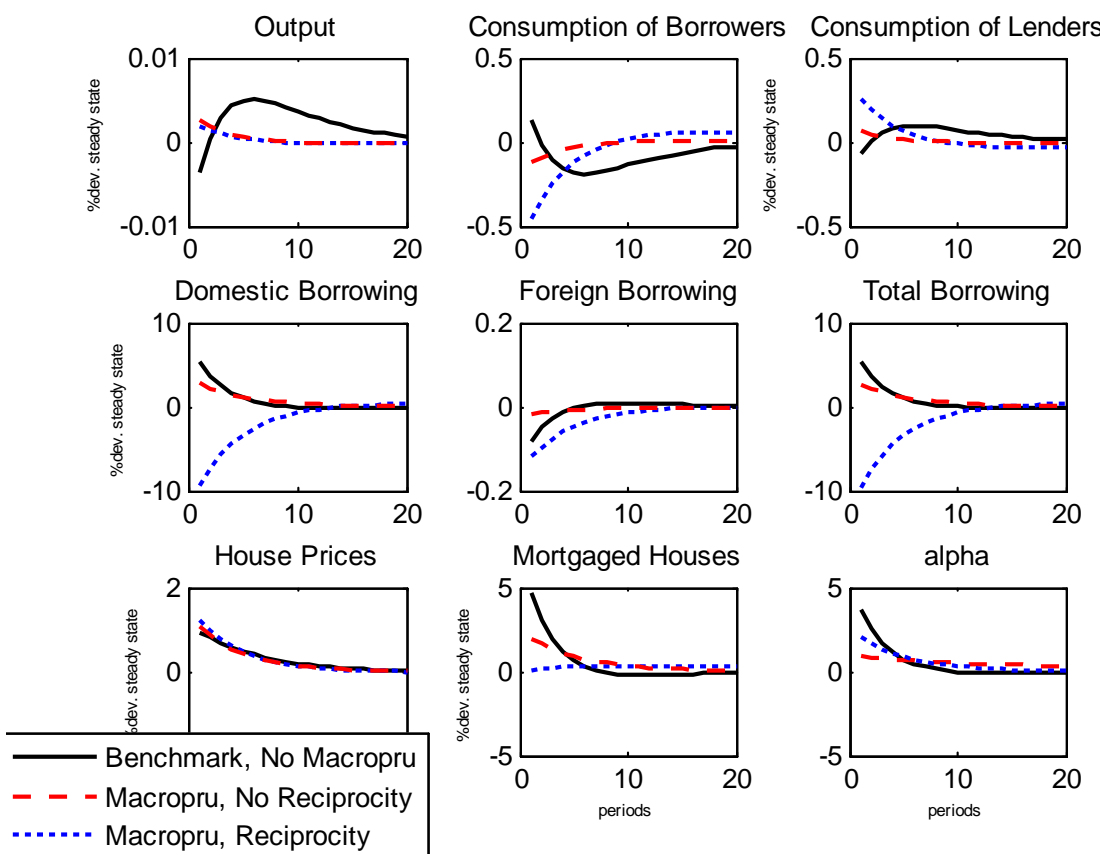

Figure 6: Impulse Responses to a House Price Shock

shock are similar to the ones in the previous figure, since it is also an expansionary shock. An increase in house prices increases the demand for borrowing through the collateral constraint. However, if there are macroprudential policies, the collateral constraint becomes tighter. If there is no reciprocity, this happens just for the domestic constraint and thus we can observe leakages from macroprudential policies. There is a redistribution of debt between domestic and foreign. Although domestic borrowing increases relatively less compared to the benchmark with the introduction of a stricter regulation, if foreign lenders do not reciprocate the policy, their lending is less affected than for the case of reciprocity. Overall, the effects of the shock for the macroeconomy, although mitigated by macroprudential policies, do not depend as much on reciprocity. However, as in the previous case, financial markets behave differently depending on whether macroprudential policies are reciprocal or not.

As a robustness check, Table A1 in the Appendix shows the impact response of $\alpha$ for different combinations of the reaction parameters, including the optimal values, as a sensitivity check. We can see that qualitatively, results are maintained for the different values of these parameters. On impact, the stricter the regulation in the home country, the more effect macroprudential policies have on domestic debt. However, it is still the case that, as regulation in the foreign economy also becomes stricter, foreign lending also gets affected. 


\subsubsection{Financial Stability and Welfare}

In light of the results on dynamics, Table 3 displays the effects of macroprudential policies on welfare, financial stability, and the standard deviation of some key variables, for the same value of the parameters as above: ${ }^{18}$

Table 4: Financial Stability and Welfare

\begin{tabular}{|c|c|c|c|c|c|c|c|c|c|c|}
\hline & \multicolumn{7}{|c|}{ Model moments } & \multicolumn{2}{|c|}{ Data moments } & \multirow[t]{2}{*}{ Welfare Gain } \\
\hline & $\sigma_{b^{H}}$ & $\sigma_{b^{F}}$ & $\sigma_{b^{T}}$ & $\sigma_{R}$ & $\sigma_{q}$ & $\sigma_{c g a p}$ & $\sigma_{h g a p}$ & $\sigma_{b^{H}}$ & $\sigma_{b^{F}}$ & \\
\hline No Macropru & 6.90 & 0.101 & 5.16 & 0.223 & 1.753 & 2.315 & 7.961 & 4.32 & 1.07 & - \\
\hline Macropru-No Reciprocity & 5.48 & 0.106 & 3.818 & 0.16 & 1.775 & 0.352 & 1.890 & & & 0.97 \\
\hline Optimal Macropru & 1.45 & 0.011 & 0.104 & 0.106 & 2.235 & 0.337 & 0.815 & & & 1.32 \\
\hline
\end{tabular}

Note: Table 4 reports measures of financial stability and welfare gains for the benchmark case, the no reciprocity case and the reciprocal optimal case.

Welfare analysis, in models with financial frictions, deserves some discussion. In models with collateral constraints, welfare involves a number of issues not considered in standard models. In the presence of constrained individuals, credit availability subject to collateral constraints introduces a distortion, which creates conflicts and trade-offs between borrowers and savers. Welfare evaluation needs to take into account this heterogeneity between savers and borrowers. Although most of the literature on DSGE models with financial frictions approaches welfare analysis from a numerical point of view, there have been few attempts to analytically derive a welfare-based loss function in models with collateral constraints (See for instance Ferrero et al., 2018 and Andres et al, 2013). These papers conclude that, in the presence of financial frictions, the relevant terms for welfare are not the levels and volatilities of total consumption or housing but the consumption and the housing gap. These gaps refer to the difference between the consumption and housing of borrowers and savers. They arise from the heterogeneity between the two types of agents in terms of their access to finance. In fact, one group of households are credit constrained while the other is not. Savers could insure each other against the variation in their housing and consumption bundles, while borrowers are limited by the amount of housing collateral. Collateral constraints prevent borrowers from smoothing their consumption as savers do, following the Euler equation. As for the housing gap, borrowers' demand for real estate is distorted because it serves as

\footnotetext{
${ }^{18}$ Model moments are found simulating the model 100,000 times feeding in the two shocks simultaneously.
} 
collateral. The gaps of consumption and housing between optimizing savers and constrained borrowers give policymakers a measure of the welfare loss associated with the financial friction. Therefore, policies that manage to effectively close these gaps (or their variance) will be welfare enhancing.

Table 4 summarizes the key elements that have to do with financial stability and welfare in this model. The first row of the table constitutes the benchmark case, when there are no macroprudential policies in place. The columns show the standard deviations of borrowing and the standard deviations of the interest rate and house prices, as a proxy of financial stability. I include all these variables because when it comes to macroprudential policy, policymakers care about both price and quantity. That is, the lower the standard deviations the more stable financial markets are. The first column corresponds to the standard deviation of borrowing from domestic lenders, the second one is borrowing from foreign lenders, the third one is total borrowing, and the fourth one is the interest rate, which in equilibrium is equal to the domestic and foreign interest rates. If we compare the standard deviations with the ones found in the data (data moments columns), we find that qualitatively the model is able to capture that the standard deviation of domestic loans is larger than the same for foreign loans (4.32 vs. 1.07, respectively). However, the ratio is larger in the model than in the data. I have also included in the table the standard deviation of both the consumption and the housing gaps, for the benchmark case, and the both the reciprocal and the non reciprocal macroprudential policy settings, which are the relevant variables to understand welfare gains (presented in the last column).

Results shown in this table confirm the case that macroprudential policies have an impact on financial markets and that the effects are different depending on whether there is reciprocity in policies or not. As we can observe, when there are macroprudential policies, the standard deviation of borrowing and the interest rate, no matter the source, decrease. However, gains in terms of financial stability are larger if there is some sort of reciprocity among policies. Seeing from Figure 5 and Figure 6, mortgaged housing remains virtually constant in response to both the productivity and the housing demand shock in case of reciprocity. This is because, the policy reciprocity shifts the credit supply curve inwards if there is an outward shift in the credit demand curve. This implies that the housing price is actually more volatile in case of reciprocity, as shown in Table 3. The reciprocity achieves financial stability of quantity variables, but not price variables.

In terms of welfare gains, it is also desirable that macroprudential policies are reciprocal. In other words, non reciprocity in macroprudential policies can partly "undo" their purpose of achieving financial 
stability and high welfare. ${ }^{19}$ We see that, in this paper, as in for instance Ferrero et al. (2018), introducing macroprudential policies significantly closes the consumption and housing gap, especially the latter one. We can see this by a reduction in the standard deviation of both gaps that these policies imply. The use of the LTV as a macroprudential policy makes that a tightening of macroprudential policy limits the increase in debt and succeeds in stabilizing the housing gap in particular. Macroprudential policies prevent borrowers from borrowing as much as they would if the policy were absent and that makes them devote less resources to consumption and housing. Housing prices, as we have seen in the impulse responses and we also see from the table, are more volatile with macroprudential policies and this makes housing less appealing for savers. All these effects together, close the gaps between the two agents, especially in the housing side, and this gives rise to higher welfare. When it comes to reciprocity, the macroprudential policy is more restrictive because it applies to all loans (domestic and foreign) and the effects on the gaps are more remarkable. This makes that the gap volatility decreases even more and the welfare effects are larger.

\section{Concluding Remarks}

In this paper, I use a DSGE model to study the effects of macroprudential policy leakages when there are foreign banks operating in the domestic economy and regulation is not reciprocal. The model features patient and impatient agents, namely lenders and borrowers, respectively. Borrowers face collateral constraints and can borrow from domestic and foreign lenders. Macroprudential policies are represented by a rule on the LTV. Macroprudential policies can be applied just to domestic lenders or to both types of lenders, if there are some sort of reciprocity agreements.

Within this framework, I explore how the share of domestic borrowing, financial stability and welfare are affected by the lack of reciprocity in macroprudential policies, a phenomenon known as leakage. I find that, when financial regulation is stricter for domestic lenders than for foreign ones, funds tend to go to the less regulated sector. However, if policies are reciprocal, that is, foreign lenders also follow domestic regulation, leakages are less important. Results show that reciprocity in macroprudential policies delivers higher welfare gains than non reciprocity, with respect to a situation in which policies are not in place. This welfare gain comes from the fact that consumption and housing gaps between savers and borrowers are closed by the macroprudential policy, especially if there is reciprocity. A larger improvement in

\footnotetext{
${ }^{19}$ It has to be acknowledged that the welfare gains from reciprocity within the macroprudential policy are relatively more limited than the gains from introducing the policy itself.
} 
financial stability is also achieved.

I find that, in order to maximize welfare, some sort of reciprocity agreements are desirable. However, the macroprudential rule for foreign lenders does not need to be as aggressive as the domestic one, reflecting the fact that borrowers have a preference for domestic lenders. The macroprudential policy with reciprocity has to be strong enough so that the total borrowing should decrease in order to keep equilibrium housing virtually constant in response to expansionary shocks. 


\section{Appendix}

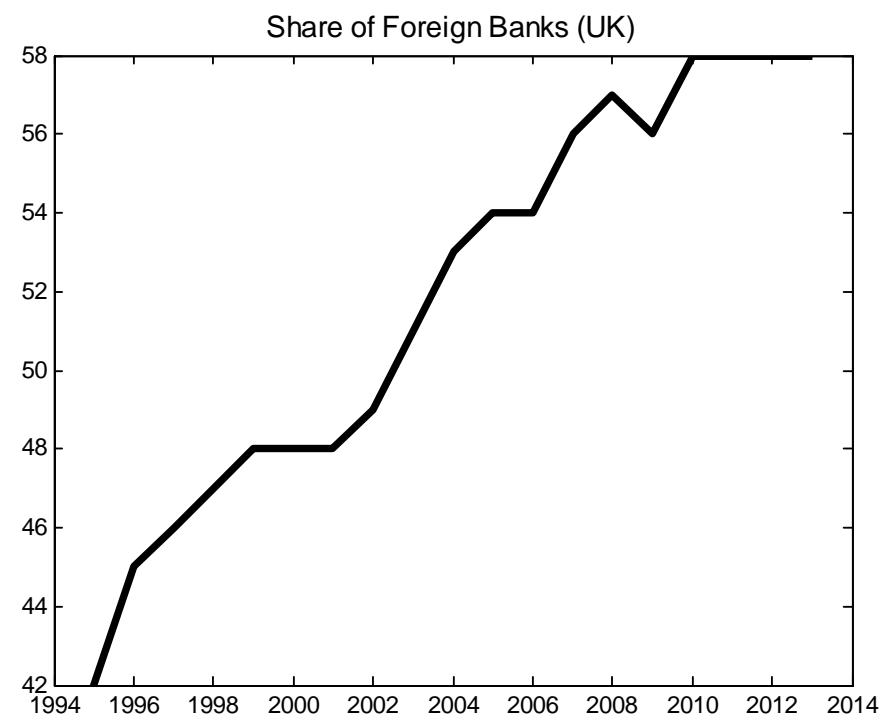

Figure A1: Percentage of Foreign Banks Among Total Banks for United Kingdom, Percent, Annual, Not Seasonally Adjusted (FRED)

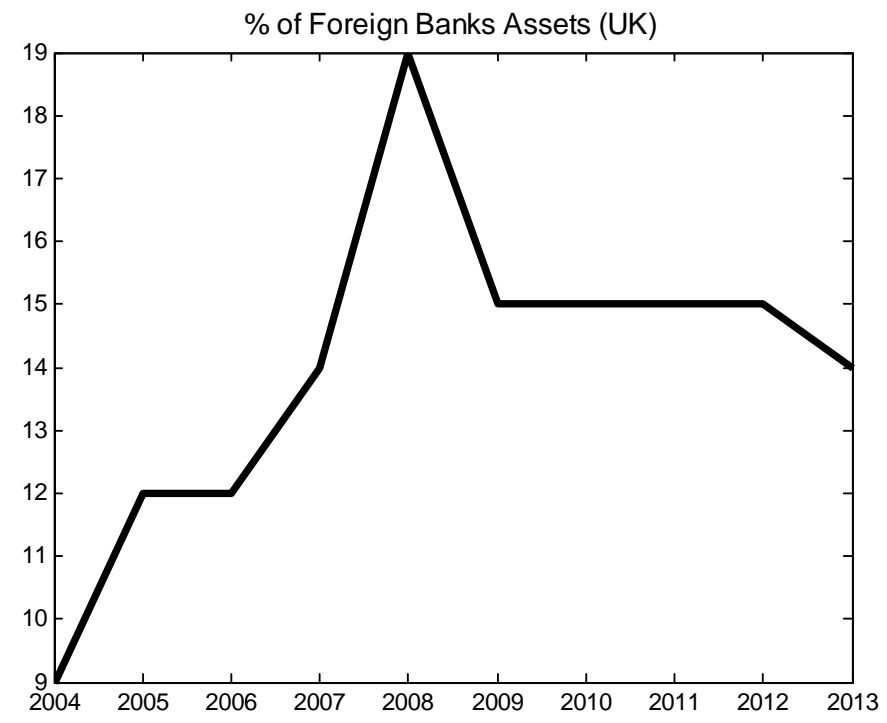

Figure A2: Percentage of Foreign Bank Assets Among Total Bank Assets for United Kingdom, Percent, Annual, Not Seasonally Adjusted (FRED) 


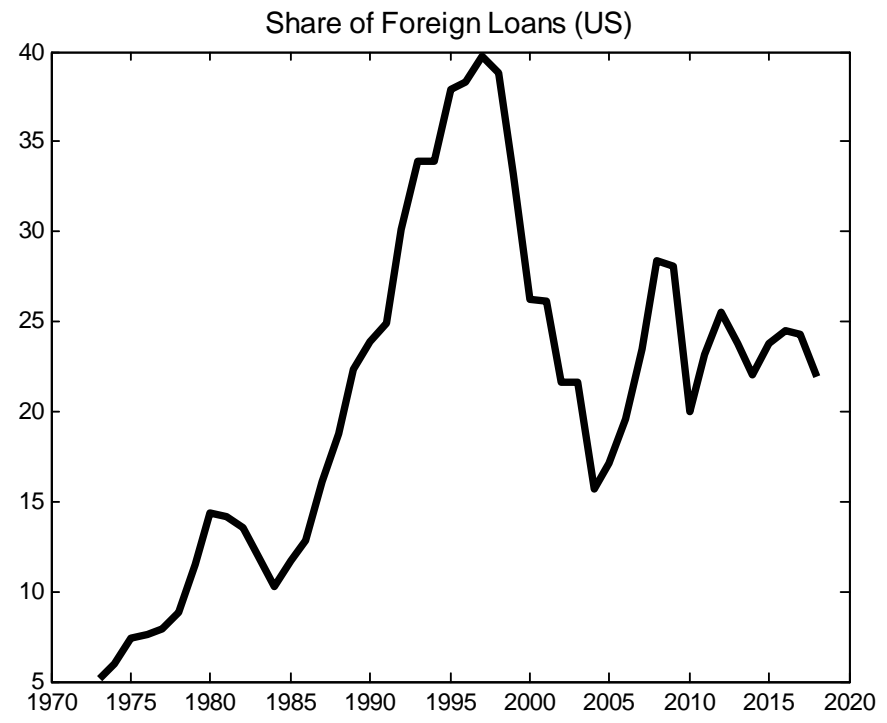

Figure A3: Commercial and Industrial Loans, Foreign-Related Institutions, over Commercial and Industrial Loans, Domestically Chartered Commercial Banks, Billions of U.S. Dollars, Seasonally Adjusted. Source: FRED

\begin{tabular}{c|c|cc}
\hline \hline \multicolumn{3}{c}{ Table A1: Rule parameters. Sensitivity analysis } \\
\hline \hline$\phi_{H}$ & $\phi_{F}$ & \multicolumn{2}{c}{$\alpha$ Response (\% dev. SS) } \\
\hline & & Technology Shock & House Price Shock \\
\cline { 3 - 4 } 0 & 0 & 2.7924 & 3.6455 \\
8 & 0 & 0.5107 & 1.0259 \\
8 & 0.2 & 0.5928 & 1.1481 \\
8 & 0.3 & 0.6290 & 1.4622 \\
8.5 & 0 & 0.7735 & 0.8519 \\
8.5 & 0.2 & 0.8098 & 0.9417 \\
8.5 & 0.3 & 0.9115 & 1.0144 \\
9 & 0 & 0.5815 & 0.7624 \\
9 & 0.2 & 0.6471 & 0.8798 \\
9 & 0.3 & 0.7271 & 0.9976 \\
\hline \hline
\end{tabular}




\section{References}

[1] Aiyar, S, Calomiris, C., and T. Wieladek (2014), "Does Macro-Prudential Regulation Leak? Evidence from a U.K. Policy Experiment, "Journal of Money, Credit and Banking, 46 (1), pp. 181214

[2] Aiyar, S, C. Calomiris, J. Hooley, Y. Korniyenko, and T. Wieladek (2014), "The International Transmission of Bank Capital Requirements: Evidence from the United Kingdom, "Journal of Financial Economics 113 (3), pp. 325-518

[3] Andres, J., Arce, O., and C. Thomas (2013), "Banking competition, collateral constraints, and optimal monetary policy," Journal of Money, Credit and Banking 45 (s2), 87-125.

[4] Angelini, P., Neri, S., Panetta, F., (2014), "The Interaction between Capital Requirements and Monetary Policy." Journal of Money, Credit and Banking, Volume 46, Issue 6, pp. 1073-1112

[5] Arregui, N., Benes, J., Krznar, I., Mitra, S., Oliveira Santos, A., (2013), Evaluating the Net Benefits of Macroprudential Policy: A Cookbook, IMF Working Paper 13/167

[6] Ascari, G., Ropele, T., (2009), Disinflation in a DSGE Perspective: Sacrifice Ratio or Welfare Gain Ratio?, Kiel Institute for the World Economy Working Paper, 1499

[7] Benigno, P., Woodford, M., (2008), Linear-Quadratic Approximation of Optimal Policy Problems, mimeo

[8] Claessens, S., Van Horen, N., (2012), Foreign Banks: Trends, Impact and Financial Stability, IMF Working Paper WP/12/10

[9] Chan, J., Columba, F., (2016), Macroprudential and Monetary Policy Interactions in a DSGE Model for Sweden, IMF Working Paper

[10] Danisewicz, Piotr, Reinhardt, Dennis and Sowerbutts, Rhiannon, (2015) "On a tight leash: does bank organisational structure matter for macroprudential spillovers? "Bank of England working papers 524, Bank of England

[11] Domeij, D., Flodén, M., (2006) "The Labor-Supply Elasticity and Borrowing Constraints: Why Estimates are Biased." Review of Economic Dynamics, 9, 242-262 
[12] ECB (2015), Financial Stability Review

[13] ESRB (2016), Macroprudential Policy Beyond Banking: An ESRB Strategy Paper

[14] Ferrero, A., Harrison, R., and B. Nelson, (2018), Concerted efforts? Monetary policy and macroprudential tools, Bank of England Staff Working Paper No. 727

[15] Hermalin, B. E., and A. K. Rose, (1999) "Risks to lenders and borrowers in international capital markets," in Martin Feldstein, ed.: "International capital flows", Chicago University Press

[16] Iacoviello, M. (2005) "House Prices, Borrowing Constraints and Monetary Policy in the Business Cycle." American Economic Review, 95 (3), 739-764

[17] Iacoviello, M., Minetti, R., (2003), Domestic and foreign lenders and international business cycles. Working Paper 554, Boston College

[18] Iacoviello, M., Minetti, R. (2006), "International Business Cycles with Domestic and Foreign Lenders, "Journal of Monetary Economics, Vol. 53, No. 8, pp. 2267-2282

[19] Kannan, P., Rabanal, P. and A. Scott (2012): "Monetary and Macroprudential Policy Rules in a Model with House Price Booms", The B.E. Journal of Macroeconomics, Contributions, 12 (1)

[20] Lawrance, E., (1991), "Poverty and the Rate of Time Preference: Evidence from Panel Data", The Journal of Political Economy, 99 (1), 54-77

[21] Mendicino, C., Kalin, N., Suarez, J. and Supera, D., 2015, "Welfare Analysis of Implementable Macroprudential Policy Rules: Heterogeneity and Trade-offs," ECB Working Paper

[22] Monacelli, T., (2006), "Optimal Monetary Policy with Collateralized Household Debt and Borrowing Constraint," in conference proceedings "Monetary Policy and Asset Prices" edited by J. Campbell

[23] Rajan, R. G., and L. Zingales (1998) "Which capitalism? Lessons from the East Asian Crisis," Journal of Applied Corporate Finance, 11, 3, 40-48

[24] Ramey V. A., and M. D. Shapiro (2001), "Displaced Capital: a Study of Aerospace Plant Closings," Journal of Political Economy, 109, 5, 958-992

[25] Rubio, M. (2011), "Fixed- and Variable-Rate Mortgages, Business Cycles, and Monetary Policy," Journal of Money, Credit and Banking, Vol. 43, Is. 4 
[26] Rubio, M., Carrasco-Gallego, J.A., (2014), "Macroprudential and monetary policies: Implications for financial stability and welfare," Journal of Banking and Finance, Vol. 49, 326-336

[27] Schmitt-Grohe, S., Uribe, M., (2004), "Solving Dynamic General Equilibrium Models Using a Second-Order Approximation to the Policy Function," Journal of Economic Dynamics and Control, $28,755-775$

[28] Viñals, J., Nier, E., (2014), "Collective action problems in macroprudential policy and the need for international coordination," Banque de France, Financial Stability Review, No. 18 